\title{
Orta Çă̆’da Sistersiyen Ekonomisi Üzerine Bir Değerlendirme
}

\author{
Halil YAVAŞ* [D
}

ÖZ

Çalışmamızda, Sistersiyen tarikatının Orta Çağ Avrupası'ndaki (1100-1450) ekonomik faaliyetlerini ele alacağız. Bu tarikat, bataklık, kumsal ve çalılıklardan oluşan atıl durumdaki arazileri değerlendirmesi ve yeni tarım teknikleri geliştirmesiyle adını duyurmuştur. Öyle ki ilerleyen dönemde, Avrupa'nın en önemli şarap ve yün üreticilerinden birisi olurken, elde ettikleri ürünlerin ticaretini de bizzat kendileri yapmışlardı. Sistersiyen ekonomisinin temel unsurlarından birisi laik biraderlerdir. Bunlar ruhban sınıfı dışından olup manastır bünyesinde hizmet eden dindar kişilerdir. Makalemizde Sistersiyen tarikatını bazen Benedikten ve Kluni tarikatları ile kıyaslayacağız. Bu kıyaslamada onların diğer tarikatlara göre ne kadar çalışkan oldukları anlaşılmaktadır. Ancak olumlu ifadelerin yanı sıra özellikle dönem kaynaklarında onlara yönelik yapılan eleştirilere de değineceğiz. Çünkü Sistersiyenler aşırı bir şekilde hırslı ve açgözlü olmakla suçlanmışlardı. O zamanki dini yapıların gösterişli yaşam sürmelerine tepki olarak ortaya çıkmış olmalarına karşın üç kuşak sonra kendileri de benzer bir duruma düşmüşlerdi. Bu eleştirilere rağmen Sistersiyen tarikatı Avrupa'daki tarımın iyileştirilmesinde ve Baltık bölgesinin kolonizasyonlaştırılmasında önemli misyonlar üstlenmişti. Makalemizin sonlarında, onların bu çalışmaları ile Anadolu'da Beylikler ve Osmanlı’nın kuruluş dönemindeki dervişlerin benzer faaliyetlerine değinip, bazı karşılaştırmalarda bulunacağız.

Anahtar Kelimeler: Sistersiyenler, Manastır, Orta Çă̆, Değirmen, Şarap
\end{abstract}

\section{An Assessment of the Cistercian Economy in the Middle Ages}

\begin{abstract}
In our study, we will consider the economic activities of the Cistercian order in medieval Europe. This order has made a name for itself by opening the fields of marshes, beaches and bushes to agriculture and developing new agricultural techniques. At that time, they were one of the most important wine and wool producers in Europe. They also traded the products they produced themselves. One of the main elements of the Cistercian economy was the lay brothers. These are religious people who are outside the clergy and serve in the monastery. In our article we will sometimes compare the Cistercian order with the Benedictine and Kluni orders. In this comparison, it is understood how hardworking they are compared to other orders. However, in addition to the positive statements, we will also mention the criticisms made against them, especially in the primary sources. Because the Cistercians were accused of being excessively greedy. Although they emerged as a reaction to the luxury lives of the orders of that time, they themselves fell into a similar situation three generations later. Despite these criticisms, the Cistercian order had important missions in improving agriculture in Europe and colonizing the Baltic region. At the end of our study, we will touch on the similar activities of the dervishes in the period of the Beyliks in Anatolia and the founding period of the Ottoman Empire, and make some comparisons.

Keywords: Cistercians, Monastery, Middle Ages, Mill, Wine
\end{abstract}

\section{Giriş}

Her yeni tarikat, eski tarikatların yozlaşmasını düzeltmek için kurulduğunu iddia etmiştir. Kluni tarikatı, X. yüzyllda Benediktenleri; Sistersiyenler Klunileri; Fransiskenler ve Dominikenler ise Sistersiyenleri izlemiştir. (Thompson, 1928, s. 603). Benedikten manastırları geniş arazilere sahip olup zenginleştikçe, amaçlarından uzaklaştıklarıyla ilgili eleştiriler almaktaydı (Honour, 2015, s. 328). Özellikle Kluni tarikatının zenginliği bu süreçte daha çok dikkat çekmekteydi (Honour, 2015, s. 369). Mevcut gidişattan rahatsız olanlar arasında yer alan Molesme manastırı başrahibi Robert, yanına Alberic ve Stephen'in de aralarında olduğu yirmi bir keşişi alarak, 21 Mart 1098'de Burgonya'da Cistel ormanlarında, Cîteaux (Latince Cistercium) $^{1}$ köyünde yeni bir manastır kurmuştu (Barrett, 1913, s. 123; Aşıkoğlu, 2009, s. 46). Ancak hatalarını kabul eden Molesme'deki keşişler Robert'ı dönmesi hususunda ikna etmişlerdi. Böylece Robert, Haziran 1099'da yeni manastırın idaresini Alberic'e bırakarak eski manastırnna dönmüştü. Alberic, 1109'da vefat ettiğinde manastır, kurucularının ideallerine uygun olarak yoksulluk içinde kötü yaşam şartlarında varllğını sürdürmekteydi (Burton \& Kerr, 2011, s. 10; Aşıkoğlu, 2009, s. 47). Alberic’ten sonra göreve

* Dr. Öğr. Üyesi, Hitit Üniversitesi, halil.yavas@yahoo.com

Makalenin Gönderim Tarihi: 11.03.2021; Makalenin Kabul Tarihi: 04.08.2021

doi: $10.52642 /$ susbed. 895242

${ }^{1} \mathrm{O}$ dönemde Citeaux civarı çalılık, bataklık ve çok sayıda göletin bulunduğu bir alandı. İsmin etimolojik kökeninin de bu durumla ilgili olduğu düşünülmektedir. Ünlü Fransız filolog Du Cange, Cistercium sözcügünü, "durgun havuzlu bir bataklık” olarak açıkladığı Cisternae kelimesinden türediğini ifade etmektedir. Bkz. Mason, 1905, s. 169. 
gelen Stephan Harding isimli başrahip döneminde, özellikle de sonraki başrahiplerden olan Bernard'ın 1112'de tarikata girmesiyle birlikte bu durum değişmeye başlamıştır. Buna rağmen Stephen, sade yaşam konusunda hassas olmayı sürdürmüştür. Hatta lortlar ile arasına mesafe koymuştur (Burton \& Kerr, 2011, s. 11). Ayrıca haç başta olmak üzere altın veya gümüşten yapılmış eşyaların manastır içinde kullanımını kaldırmıs, hatta kiliselerin demirden yapılmış tek bir şamdan ile aydınlatılmasını emretmiştir (Dalgairns, 1898, s. 89).

Stephen'nn en önemli icraatlarından birisi tarikatın anayasası kabul edilen Charta Caritatis isimli belgenin 1119'da Papa II. Calixtus'un da onayıyla ilan edilmesidir. Zaten büyüme eğiliminde olan tarikat bu belgeyle birlikte kurumsallaşmaya başlamıştır (Bury, 1926, s. 672). Charta Caritatis, genel olarak manastırların idare şeklini ve kendi içlerindeki işleyişi düzenlemektedir. Belgenin 4. maddesinde bir manastırın başrahibinin, kendisine bağlı diğer manastırları her yıl ziyaret edeceği belirtilir. Yine aynı maddede her yıl Cîteaux'da genel toplantı yapılması bildirilmiştir. Bu toplantının amacının ele alındığı 6. maddede, hatalı rahiplerin uyarılması veya tekrarı söz konusuysa cezalandırlması istenmektedir (Charta Caritatis, 2021).

Tarikatın en büyük atılımı, Haçlı seferlerine katılmış bir şövalyenin oğlu olan Clairvauxlu Bernard döneminde olmuştur. Sistersiyenler, Bernard'dan önce iflasın eşindeyken onunla birlikte göz kamaştırıcı bir servete kavuşmuşlardır (Baigent \& Leigh, 2005, s. 95). O, 1112'de tarikata girdikten üç yll sonra Champagne kontu Hugues'ün hibe ettiği, "haydut sığınağı" diye bilinen ormanlık Wormwood vadisinde on iki arkadaşıyla birlikte bir manastır kurmuştur. Akabinde vadinin ismini Clairvaux, yani "Işı1k Vadisi” olarak değiştirmişlerdir (Akın, 2005, s. 92). Bernard'ın yönetimindeki Clairvaux manastırı onun baskın kişiliği sayesinde asıl merkez olan Citeaux manastırına yakın bir otoriteye sahip olmuştur. Bu durum sonraları bazı eleştirilere yol açmış ancak sorun Bernard hayattayken bir krize dönüşmemiş ve onun ölümüyle de kendiliğinden son bulmuştur (Aşıkoğlu, 2009, s. 49).

$\mathrm{Bu}$ arada bazı araştırmacılar Sistersiyenlerin Aziz Bernard sonrasında ekonomik atılım içine girmesini, Tapınak şövalyeleri ile ilişkilendirmektedirler. Çünkü Bernard'ın amcası Andre de Montbard Tapınak şövalyelerinin kurucuları arasında yer almaktadır. Bu iddiayı savunanların bir diğer dayanak noktası ise Tapınak şövalyelerinin bazı Sistersiyen adet ve törenlerini benimsemesidir. Ayrıca her iki tarikatın büyüme dönemlerinin aynı yıllara denk gelmesi de buna delil gösterilmektedir (Baigent \& Leigh, 2005, s. 95; Odabaşı, 2019, s. 403). Ancak anladığımız kadarıyla bu hususta somut bir belge bulunmamaktadır.

Sistersiyenler erken dönemlerden itibaren Burgonya dışında manastır kurmaya başlamışlardı. Bernard ile birlikte bu sayı hızla artmıştır. 1127'de Almanya (Ebrach) 1128'de İngiltere (Waverley) 1132'de Leon (Moreruela), 1140'da Galler (Whitland), 1142'de İrlanda (Mellifont), 1143'te İsveç (Ahastra) ve 1144'te Danimarka (Herrevad) Sistersiyen manastırlarılla tanışmışardı. (Bury, 1926, s. 677). Avrupa'nın batısında Sistersiyenler, mevcut manastırların amaçlarından uzaklaşmasına tepki olarak ortaya çıkmışken, Hırvatistan'da kraliyet otoritesinin davet ve teşviki ile varlık göstermişlerdi (Ancic, 1997, s. 207). Macaristan'da da benzer bir durum ortaya çıkmıstır. Bir Fransız ile evli olan Macaristan kralı III. Bela (1173-1196), Almanlara karşı bir denge oluşturmak için Fransızları desteklemekteydi. Bu politikasının bir devam1 olarak 1183'te Sistersiyenleri ülkesine davet etmişti (Thompson, 1928, s. 534). Tarikat, Almanya'daki güçlü pozisyonlarının da etkisiyle olsa gerek ki Livonya'da da sayıları hızla artmışı. Hatta 1209 'da Ortodoks Rusya'da birçok ticari koloni kurmuşlardı (Thompson, 1928, s. 621).

\section{Tarım}

Sistersiyen ekonomisini ortaya çıkaran düşünce biçiminin temelinde "sadelik" arayışı yatmaktadır diyebiliriz. Çünkü bu anlayışın neticesinde onlar toprakla ve hayvancılıklar ilgilenmişlerdir. Kluni tarikatına en çok karşı çıkma nedenleri, onların zenginleşmeleri ve gösterişe meyletmeleriydi. Sistersiyenler ise buna tepki olarak Benedikten kurallarının emrettiği şekilde sade yaşama sarılmak için toprağı kendileri işlemeye ve dilenmeden ihtiyaçlarını karşılamaya karar vermişlerdi. Öyle ki giydikleri beyaz elbise de bu düşüncenin bir tezahürüdür (Cantarella, 2014, s. 387). Bernard'nn Bizans'tan etkilenerek Katolik dünyaya tanıttı̆̆1 "Bakire Meryem" saflığı da yine bu anlayışın bir yansıması olduğu ileri sürülmektedir (Tannahill, $2003 \mathrm{~s}$. 230). Boyanmamış yünden yapılmış kıyafetler giyen bu kişilerin o dönem "havari gibi" yaşadıkları 
düşünülmekteydi (Walter Map, 1983, s. 77). Bu tevazu, mimaride de görülmektedir. ${ }^{2}$ Sistersiyenlerin el emeğiyle kendi ihtiyaçlarını karşılama düşüncesi 1134 'teki toplantıda alınan karar doğrultusunda tarikatın mevzuatına da girmişti (Jamroziak, 2003, s. 200). Yaşayabilecek kadar üretmeli ve kalan vakitte de ibadet edilmelidir (ora et labora) (Akın, 2005, s. 93). Oluşturulan manastır bahçeleri, keşişlerin ve rahibelerin vejetaryen beslenme alışkanlıklarının sürdürülebilmesinin yanı sıra konukların rahatça ağırlanabilmesine de imkân sağlamaktaydı. Ayrıca şifalı otlar yetiştirmekte ve alanında uzman manastır üyeleri tarafından bu otlardan muhtelif ilaçlar hazırlanmaktaydı (Akın, 2005, s. 63).

Sistersiyen tarımının temelinde grange denilen çiftlik sistemi yer almaktadır. Tahıl ambarı anlamına gelen bu sözcük, birçok ürünün yetiştirilmesinin yanında muhtelif zanaatların da icra edildiği geniş tarım alanlarını ifade etmektedir (Bishop, 1936, s. 193). Bu yerler, grange master veya granger denilen bir laik birader tarafindan yönetilmekteydi. Bu çiftlikler aynı zamanda üretim faaliyetlerinin de yürütüldüğü küçük yerleşim merkezleriydi (Berman, 1986, s. 61-62). Bir Sistersiyen manastır1 farklı bölgelerde olmak üzere toplamda yaklaşık beş ila sekiz bin hektar araziye sahip olabilmekteydi. Bu sayı Clairvaux'da yirmi sekiz bin hektara ulaşmıştı (Aşı1koğlu, 2009, s. 50; Pirenne, 2012, s. 83). Gaskonya'da bastid denilen savunma amaçlı yerleşimler için seçilen çiftlikler genellikle diğerlerine nazaran daha küçüklerdi. Bunun da sebebi bu iş için daha az üretim yapan çiftliklerin tercih edilmesiydi (Berman, 1986, s. 63).

Çiftliklerdeki en önemli yapı bu geniş arazileri işletmek ve korumak için, Stephen Harding ile uygulamaya konan, Sistersiyen manastırlarına özgü çiftlik evleridir. Manastır kilercisinin denetiminde, laik biraderlerin işlettiği bu yapıların manastıra uzaklığı beş ila otuz kilometre arasında değișmekteydi. Otuz kilometre, bir günlük yürüyüş mesafesi olup, daha uzak olmamasına dikkat edilmekteydi (Aşıkoğlu, 2009, s. 50). Böylece oralarda çalışan laik biraderler, pazar ayinlerine ve diğer özel günlerdeki ritüellere katılmak için rahatça manastıra ulaşabilmekteydiler (Burton \& Kerr, 2011, s. 168). İlk zamanlarda bazı çiftliklerde küçük kiliseler inşa edilmekle birlikte 1204'teki genel toplantıda, çiftlik evlerinin bağımsız bir manastır sayılabilme endişesiyle bu kiliseler kapatılmıştır (Aşıkoğlu, 2009, s. 50). Bu evlerden günümüze kalan en eski yapı XIV. yüzyıla ait olup Güney Fransa'da bulunmaktadır (Berman, 1986, s. 63).

Sistersiyenlerin tarım sistemindeki bir diğer önemli unsur laik biraderlerdi. Tarikatta fiziki olarak çalısmak çok övülmüşse de bir süre sonra ağır işleri laik biraderlere bırakmışlardı. Aziz Benedikt kuralları, orada yaşayan ve oblates denilen dindar kişilerin manastırlara girip hizmet etmelerine izin vermekteydi (Thompson, 1920, s. 76). Bu yöntem ilk defa, St. John Gualbertus tarafindan 1038'de kurulan Vallombrosa tarikatında uygulamaya konmuştur (Thompson, 1928, s. 612). Kluni tarikatının da tatbik ettiği sistemi, Sistersiyenler çok daha işlevsel ve de yaygın bir şekilde kullanmışlardır (Lawrence, 2017, s. 162). Citeaux'nun kuruluşundan yirmi yıl sonra teşkilatın büyümesine bağlı olarak Stephen Harding, manastırnn ağır işlerinde kilise dışından yani profan sınıftan kardeşler bulundurulması kararı almıştı. Burada amaç, manastırların varlıklarını daha verimli şekilde kullanmak ve rahiplere ayin için gerekli zamanı sağlayabilmekti (Burton \& Kerr, 2011, s. 151). Bu kişiler genellikle yerel halktan seçilmekle birlikte farklı uygulamalar da görülmüştür. Hirvatistan'da halk ile sorun yaşayan manastırlar kraliyet otoritesinin de desteğiyle varlıklarını korumuşlar ancak insan kaynağı noktasında sorun yaşamışlardı. Bunun neticesinde ihtiyaç duydukları laik biraderleri Fransa'dan getirmişlerdi (Ancic, 1997, s. 218).

Manastırlara ait çiftliklerde, ormanlarda, taş ocaklarında ve madenlerde uzun ve yoğun emek gerektirecek işlerde çalışmakta olan laik biraderler, aynı zamanda rahipler ile dış dünya arasındaki irtibatı sağlayıp, onların daha fazla ibadete yönelmelerine hizmet etmekteydi (Thompson, 1928, s. 612). Genel olarak bu sınıf, toprak düzeninde istihdam edilemeyen işgücü fazlasından oluşturulmuştu (Pirenne, 2012, s. 84). Öte yandan birçok laik birader daha önceden çiftçi, zanaatkâr, şövalye ve idareci gibi çeşitli meslekleri icra etmiş olmaları hasebiyle, Sistersiyen çiftliklerinin verimliliğine katkıda bulunmuşlardı (Kienzle, 2001, s. 41). Bu kişiler, kişisel servetlerini terk edip tarikata ve Benedikten kurallarına bağlı kalacaklarına dair yemin ederek göreve başlarlardı. Onlar, keşişlerin katıldıklanı bütün ibadetlere iştirak etmeyip, sadece sabah ve akşam ayinleri ile bazı özel günlerdeki törenlere katıllıllardı. Okur yazar olmayan sınıftan seçilen laik biraderler, tarikatın mensubu olmakla birlikte ibadetlerini koro rahipleri denilen diğer manastır üyeleri gibi

\footnotetext{
2 Sanatın kişiyi çalışmaktan ve duadan alıkoyduğunu söyleyen Bernard, sade bir mimari tarzı savunmaktaydı. Buna bağlı olarak erken dönemlerde Sistersiyen mimarisi heybet ve gösterişten uzaktı. Ancak sonrasında XIII yüzyıl boyunca sadelikten adım adım uzaklaşarak Gotik katedrallerin dekoratif üslubu benimsenmiştir. Bkz. Şahin, 2020, s. 256.
} 
ritüel şeklinde değil de tarımsal faaliyetler, hayvancıllk ve endüstriyel üretim gibi işlerde çalışarak yaparlardı. Ancak onlar da sessizlik geleneğine uymak zorundaydılar. Keşişlerin giydikleri kıyafetleri giymeyip iş elbisesi giymekteydiler. Giysilerindeki ana öğe, büyük olasılıkla manastır statüsünü simgeleyen kukuletadan yoksun bir pelerin veya mantoydu. Rahiplerin yaptıkları gibi başlarının üst kısmını tıraş etmezlerdi. Çünkü bu karakteristik saç kesimi, rahip statüsüne sahip erkekler için bir aidiyet simgesiydi. İki parmak uzunluğunu geçmeyecek şekilde sakal bırakırlardı. Bu özelliklerinden dolayı bazen "sakallı kardeşler" diye de anılmışlardır (Ziolkowski, 2018, s. 141-142). Çiftlik evlerinde veya manastırlarda keşişlerden farklı yerlerde kalmaktaydılar. Tarikata laik birader olarak giren kişilerin keşişliğe geçememesiyle ilgili katı kurallar vardı (Burton \& Kerr, 2011, s. 152). Bu farkllılk vurgusuna rağmen o zamana kadar köylülerin normal statüsü olan serflik, Sistersiyen arazilerinde hemen hemen hiç olmamıştır (Pirenne, 2012, s. 84).

Sistersiyenlerin ortaya çıktığ dönemde, ekilebilir iyi tarım arazilerinin dolu olması hasebiyle onlar da ormanların, fundalıkların ve bataklıkların olduğu atıl durumdaki alanları sslah etme yoluna gitmişlerdi (Thompson, 1928, s. 611; Pirenne, 2012, s. 82). Haylr sahipleri, demesnelerinde bolca bulunan ve kendilerinin kullanamadıkları boş arazilerden onlara büyük bağışlarda bulunmuşlardı (Pirenne, 2012, s. 83). Böylece Sistersiyenler, uzak veya daha elverişsiz alanlara yerleşmek zorunda kalmışlardı. Kuzey İngiltere veya İskoçya'daki vadi ve bataklıklar, Biskay körfezi kıyılarındaki kumlu alanlar, Slavlardan ele geçirilen Güney Baltık bölgeleri, Flandre'de gel-git akıntısının etkili olduğu sahil şeridi bu alanların başında yer almaktadır (Delmas, 1967, s. 29-30). Söz konusu yerlerde Sistersiyenler, yabani bitkileri temizleme, suyu kurutma ya da susuz bölgeye kanallar vasıtasıyla su götürme gibi muhtelif yöntemler ile işe koyulmuşlardı (Gimpel, 2004, s. 46). Walter Map, onların bu çalışkanlıkları için "Ağaģlar keserler, ağac dikerler ve arazizi düzeltirler. Calılar yerini arpaya, sögütler buğdaya ve ü̈̈̈̈m bağlarna burakır. Bu işler için onlar, dualarm kesaltmalar gerekebilir." demiştir (Walter Map, 1983, s. 75). Gerald of Wales (ö. 1220) onların çalışkanlıklarını Kluni tarikatı ile kıyaslamaktaydı. O, Kluni manastırlarına tam donanımlı verimli tarım arazileri verilse, kısa süre sonra her şeyi mahvedip yoksulluğa düşeceklerini söylemektedir. Öte yandan Gerald, Sistersiyenleri gür bir ormana koysanız birkaç yıl içinde döndügünüzde onların oralarda görkemli kilise ve çeşitli binalar ile tam donanımlı bir manastır yapmış olduklarını göreceksiniz der. Başka bir yerde de iki tarikatı şu şekilde kıyaslamaktadır: "Sistersiyenler ağırbashlhlkelar, cimrilikleri ve gelecek için planlamalar ile gurur duyuyorlard. Oysa Kluniler acgözliulïk, oburluk ve ölçüsų̈lükten muzdariptir. Sistersiyenler bir araya gelip ar gibi ber konuda birbirleriyle uyumlu bareket eder, ortak bir keseyi paylașirlar ve sabip olduklar șeyi tutumlu bir şekilde barcar. Buna karşın dindar insanlarn bağgşlarylla ayakta duran Kluniler israfş ve dağmmktular." der (Gerald of Wales, 2004, s. 90). Walter Map ise onların beyaz kıyafet giymelerini Benediktenlerin siyah cübbe giymeleriyle kıyaslayarak "kıyafetleri bile zit idi" diye yorumlamaktayd1 (Walter Map, 1983, s. 77).

$\mathrm{Bu}$ dönemde var olan tekniklerin yanı sıra kendileri de yeni teknikler geliştirmişlerdi. XII. yüzyllda, Flandre'de Scheldt nehrinin halicinde ve Kuzey Denizi kıyları boyunca, denizden toprak kazanmaya yarayan ve polder denilen setler kurulmaktaydı. Sistersiyen manastırları da aynı yönteme müracaat etmiş ve büyük bir gayretle bataklıklardaki suları boşaltmışlardı (Pirenne, 2012, s. 91). Örneğin 1139'da kurulmuş olan Les Dunes manastırı XIII. yüzylın sonuna kadar, Flandre kıyılarındaki bataklıklardan oluşan yaklaşık 25.000 dönümlük alanı verimli tarım arazisine dönüştürmüş ve üzerinde 25 çiftlik kurmuştu. Benzer faaliyetleri Doğu Prusya'daki Dünamünde manastır1 yürütmüştür. Bu alanda en büyük Sistersiyen başarıs1 ise o dönem Kuzey Almanya'nın en büyük bataklık bölgesi olarak bilinen Türingiya havzasında yer alan "Altın Çayırlar"ın (Goldene Aue) 1slah edilmesidir (Lekai, 1958, s. 211). Rothenburg kontu Christian, Görsbach köyü yakınlarındaki bu alanın bir kısmını 1144'te Walkenried manastırına bağışladıktan sonra keşişler dört yıl gibi kısa bir sürede burayı bereketli bir tarım arazisine dönüştürmüşlerdi. Akabinde bu alan, yeni bağışlarla daha da genişlemiştir. Onların başarılarını öğrenen İmparator Frederick Barbarossa, Aşağı Rieth bölgesinde benzer çalışmalar yapabilmeleri için Walkenried keşişi Jordan'a yetki vermişti. Devamında benzer şekilde Riethof, Bernigen, Görsbach, Windelhausen ve Kaldenhausen'de büyük sslah çalşmaları yapmışlar ve değirmenler kurmuşlardı. Trave nehrinin Lübeck ve Oldesloe arasında geçen bölümündeki bataklık alanlar da bu süreçte tarıma açılmıştır (Thompson, 1928, s. 615). Daha doğuya gidildiğinde pagan Slavlardan ele geçirilen araziler, locatores denilen kolonizatörlere paylaştırılırken Sistersiyenlere de büyük miktarda arazi bağışlanmıştı. Onlar da derhal buralara yerleşip büyük çiftlikler kurmuşlardı (Pirenne, 2012, s. 92). 
Tarikat ilk yıllarda bağış kabul etmeye pek sıcak bakmamaktaydı ancak sonrasında bu konuda değişikliğe gitmişlerdir. Kıta'nın tümünde Sistersiyenlere atfedilen kutsallık ve onlara duyulan güven sayesinde çok sayıda soylu, arazi bağışında bulunmuştur. Aldıkları bağışların \%69'u araziydi. Şüphesiz Kluni tarikatı başta olmak üzere diğer tarikatlara da araziler bağışlanmıştı ancak onlar bu arazileri köylülere kiralayarak değerlendirirlerken, Sistersiyenler kendileri işleyerek daha fazla kar ele etmekteydiler (Bouchard, 2009, s. 97). Tarım arazilerinin dişında ormanlıklar, nehirler ve meralar başta olmak üzere birçok mülkün kullanım hakkına sahip olmuşlardır. Hatta XII. yüzyıldaki tutanakların \% 20'si bu konuyla ilgilidir (Bouchard, 2009, s. 106). Bağışın yanı sıra ilerleyen süreçte başta İngiltere'de olmak üzere ticari faaliyetleri neticesinde ödeme sıkıntısı çeken borçlularından arazi almışlardı (Madden, 1963, s. 347). Sistersiyenlerin hızla yeni araziler elde etmeleri Walter Map ve Galler'li Gerald gibi döneme ait yazarların onları açgözlülükle suçlayıp hicvetmelerine yol açmıştı (Kienzle, 2001, s. 41). Hatta bu durum papalığın da dikkatini çekmişti. Papa III. Alexander, tarikatın Fransa ve İngiltere'de yeni toprak elde etmekten kaçınmasını istemişti. Tarikat 1180-1206 yılları arasında Papalığın talebine uymuş ancak sonrasında bunda esnemeye gitmiştir (Lekai, 1958, s. 213).

Onlar şüphesiz teslim aldıkları arazilerin hakkını vermekteydiler. Geliştirdikleri yeni tarım teknikleri sayesinde verim artmıştı. Daha iyi sabanlar ve daha iyi el aletleri kullanmaktaydılar. En önemlisi de toprağı kireç ve hayvan gübresi ile beslemişlerdi. Ekili arazilerde dönüm başına daha fazla sayıda hayvan yetiştirilmesi toprak verimliliğini artırmada çok etkili olmuştur (Berman, 1986, s. 90-92). Demir çıkarmakla da ilgilenen tarikat çok sayıda firından elde ettiği ve fosfat yönünden zengin cürufu tarlalarda gübre olarak kullanmaktayd1 (Gimpel, 2004, s. 66). Toprağın niteliğine göre tohum seçmeyi öğrenmişlerdi (Heaton, 1985, s. 119). O dönem için oldukça yeni bir uygulama olan tohum geliştirme çalışmaları yapmışardı. Arazilerden en iyi biçimde faydalanmak amacıyla aynı sezon içinde ikinci bir ürün ekmekteydiler (Berman, 1986, s. 91). Bir keşiş, gezintiye çıktığında, manastırının çevresinde yetişebileceğini düşündügü her türlü tohum ve fidanı getirirdi. Dikkatimizi çeken bir diğer husus, doğal bitki örtüsünden faydalanarak verimli toprakların olduğu yerleri bulmaktaydılar. Şöyle ki sert ağaçların büyüdüğü yerde iyi toprağın bulunacağını öğrenmişlerdi (Thompson, 1928, s. 615).

Sistersiyen çiftlikleri bölgede alışılmışın dışında ürün çeşitliliğine sahipti. Güney Fransa'daki çiftliklerde genellikle mısır ve kışın hayvanlara yedirmek için ot yetiştirilmekteydi (Burton \& Kerr, 2011, s. 173). Fransa ve Almanya'daki Sistersiyen manastırları üzüm ve şarap üretiminde ihtisaslaşmışlardı. Oldukça katı uygulamalara sahip olan Sistersiyenlerin şarap üretimiyle ilgilenmeleri ilk bakışta şaşırtıcı gelebilir (Gimpel, 2004, s. 47). Lakin diğer tarım faaliyetlerinde olduğu gibi şarap üretimine başlamaları da öncelikle kendi ihtiyaçlarını temin etmeye yönelikti. Çünkü ayinlerinde kullandıkları şarabı kendileri üretmek istiyorlardı. İkinci nedeni ise, Aziz Benedikt'in, "idareli” olmak koşuluyla keşişlerin şarap içmelerine izin vermesidir. ${ }^{3}$ Clairvaux raporunda anlatıldığına göre üzüm veriminin kıt olduğu yıllarda, şarap yerine bira üretilmekteydi (Gimpel, 2004, s. 5). Tarikatın merkezi Burgonya, Fransa'nın en iyi şarap bölgelerindendi. Burada yer alan Citeaux Rahibe manastır1, sonradan dünyanın en ünlü bağcllık merkezlerinden biri durumuna gelecek olan Clos-Vougeot'daki çalışmalarıyla bu alanda öncülük etmiştir (Gimpel, 2004, s. 47). Grandselve, Bonnecombe ve Valmagne gibi bazı büyük manastırlar, sadece üzüm bağları yetiştirmede ve şarap üretiminde uzmanlaşmışlardı (Berman, 1986, s. 93). Almanya'da Baumgarten, Neuburg, Himmerod ve Heisterbach manastırları en iyi üzüm bağlarına sahiplerdi. Bununla birlikte, büyük şarap mahzenleri olan Eberbach manastırı, hepsini geçmişti. O bölgede ilk şarap üreticisi Sistersiyenler olmamakla birlikte önceden kimsenin kullanmadığı boş bırakılmış dik tepelerde teras benzeri yöntemler ile ekim alanı oluşturanlar onlardı (Lekai, 1958, s. 216).

Taşımacılık noktasında zor olduğu için ticari açıdan pek tercih edilmese de meyve üretimi de yapmaktaydılar. Geliştirdikleri yeni tekniklerle, özellikle kıtanın kuzey ve doğu bölgelerinde bahçeciliğin gelişmesine büyük katkıları olmuştur. 1273 'te Doberan manastırı bitki iyileştirmeleri için cam çatılı sera benzeri bir yapı yapmıştı. Manastır ağı sayesinde Fransa'daki beğenilen meyve ve sebzeler buralara getirtilip yetiştirilmekteydi. Türingiya'da elma yetiştirme ve elma şarabı yapımı bölge manastırlarının kârlı faaliyetleri

\footnotetext{
${ }^{3}$ Bununla birlikte Aziz Benedikt, şarap içmeyenler için bir ödülden söz etmiş, ancak bu ödülün ne olduğunu belirtmemiştir. Fakat şarap konusu sonraki dönemlerde hep şikâyet kalemi olmuştur. XII. yüzyıldan sonra şarap yasağıyla ilgili huzursuzluklar daha da artmıştı. Nitekim 1237'de bu konuda bazı esnemelere gidilmiştir. Bkz. Gimpel, 2004, s. 48
} 
arasında yer almaktaydı. Georgenthal ve Pforta manastırları, özellikle meyve bahçeleriyle tanınmaktaydı. Norveç'te, ülkenin en büyük manastırı olan Lyse manastırı, Hardanger bölgesinde en iyi meyve bahçelerine sahipti ki bugün de söz konusu bölge hala meyve kültürü ile ünlüdür. Aynı manastır, Bergen'de tarım ürünlerini satma ayrıcalığ elde etmişti (Lekai, 1958, s. 218). Genellikle kuzey Almanya'daki Pomerania, Mecklenburg, Brandenburg ve Plattland'da yoğun şekilde keten yetiştirilmekte ve bunlardan bir tür kanvas kumaş üretilmekteydi (Thompson, 1928, s. 618). Manastır çiftlikleri genel olarak bir üretim alanında uzmanlaşmakla birlikte umumiyetle başka alanlarda da faaliyet yürütmekteydiler (Burton \& Kerr, 2011, s. 174). Kanaatimizce bunun sebebi ihtisas sahibi oldukları alanla ilgili yaşanabilecek herhangi bir sorun çıkması durumunda, manastırın varlığını idame ettirebilmesi için hızlı bir şekilde diğer alanlara geçici veya daimi olarak kolayca yönlenebilme düşüncesidir.

Sistersiyenler birçok ormanlık araziyi tarıma açmış olmalarına rağmen bazılarını kereste ihtiyacını karşılamak amacıyla korumuşlardı. Almanya'daki Waldsassen manastırı, ormanlardan elde ettiği kerestelerin ticareti sayesinde önemli kazanç elde etmişti (Lekai, 1958, s. 211). Bazen de ormanların mülkiyeti verilmeyip kullanım hakkı verilirdi. Ancak bu yapılırken meşe ağaçlarının bundan istisna tutulduğu olurdu. Çünkü meşe inşaat işlerinde en önemli kereste kaynağı olmasının yanı sıra meşe palamudu, domuz yetiştiriciliğinde kıymetli bir yem olarak kullanılmaktaydı (Bouchard, 2009, s. 111).

\section{Hayvancilik}

Sistersiyenlerin tarımla birlikte yürüttükleri bir diğer ekonomik faaliyet hayvancilıktır. Bu amaçla çok geniş otlakların kullanım hakkına sahip olmuşlardır. XII. yüzyıldaki otlak hakları, tıpkı modern hukuktaki maden haklarında olduğu gibi, arazinin mülkiyetini etkilemeden bir kişi veya kurumun mülkiyetinden diğerine geçebilirdi. Örneğin Fransa'nın doğusundaki Belfays manastırına 1176'da geniş bir otlak hibe edilince onlar burada koyun, boğa, sı̆̆ır ve keçi yetiştirmeye başlamışlardı (Bouchard, 2009, s. 107). Fakat bu tarikatla ilgili hayvancllıktan söz edileceği zaman akla ilk İngiltere'deki koyunculuk gelmektedir. İklim koşullarının etkisiyle burada toprakların büyük bölümü mera olarak kullanılmaktadır (Heaton, 1985, s. 119). Bunu iyi değerlendiren Sistersiyenler İngiltere'de koyun yetiştiriciliğinin önemli bir kısmını elinde tutmuş̧tur. Bunun neticesinde elde ettikleri yün, Flandre ve İtalya'daki müşterilerin en çok aradıkları tekstil malzemesi olmuştur (Aşıkoğlu, 2009, s. 51). İngiltere'de koyunculuğun yanı sıra büyük baş hayvancilık da yapılmaktaydı. Örneğin Kirkstall manastırı XIII. yüzyılın sonunda 4000 koyunun yanı sıra 216 öküz, 160 inek, 152 dana ve tosun, 90 buzağyya sahipti. Ancak büyük baş hayvancilık kıtada daha da yaygindı. Fransa'da Morimond manastırı 700 sığır ve 2000 domuza sahipti. Öyle ki 1153’te Clairvaux manastırından laik biraderler, muhtemelen daha iyi cins olduğu düşünülen sığır temin etmek için İtalya'ya gitmişlerdi. Bir asır sonra, aynı manastır 900 sığırdan oluşan bir sürüye sahip olmuştu (Lekai, 1958, s. 219). İngiltere’deki kadar yaygın olmasa da Kıta'da koyun da yetiştirilmekteydi. Örneğin 1224'te Froidmont manastırının 255 inek, 450 domuz, 250 at ve katırın yanı sıra 5000 koyunu vardı. Clairvaux manastırının XIII. yüzyılda yaklaşık 3000 koyundan oluşan bir sürüsü bulunuyordu. Avusturya'daki Zwettl manastırının 1311'de tek bir çiftliğinde 2000 koyun vardı (Lekai, 1958, s. 215). Kayıtlara göre 1157 gibi erken bir tarihte bazı Sistersiyen manastırlarında At yetiştirilmekteydi. Hatta atların satışılla ilgili belirli kurallar vardı. Örneğin tayların yetişkin olana kadar satılması yasaktı (Thompson, 1928, s. 618). Svestrup manastırı (Danimarka) ile Jervaulx manastırı (İngiltere) bu alanda ünlüydü. Otterberg manastırı (Almanya), 1426'da Pfalz Prensi Louis'e 80 vahşi at sattığı kayıtlarda yer almaktadır (Burton \& Kerr, 2011, s. 174; Lekai, 1958, s. 219). Almanya'nın en kuzeyinde, Pomeranya kıyısında ve Rügen adasında soğuktan dolayı tarımın zor olmasına bağlı olarak domuz yetiştirilmekteydi. Bölgedeki geniş kayın ormanları bunun için elverişli bir ortam sağlamaktaydı (Thompson, 1928, s. 617). İlginçtir ki manastırlarda hayvancılık faaliyetlerinin artmasina rağmen köylüler tahıl merkezli beslenmeye devam etmişler ve yetersiz beslenmeye bağlı hastalıklarla mücadele etmek zorunda kalmışlard1 (Berman, 1986, s. 92).

Sistersiyenler büyük baş hayvan yetiştirmelerine rağmen kırmızı et ve domuz yağ1 tüketmezlerdi (William of Malmesbury, 1847, s. 349). Üretilen etleri ticari amaçla uzun süre muhafaza edebilmek için tuzlanarak saklarlardı. Bazı manastırlarda ise domuz pastırması ve sosis yapılmaktaydı (Thompson, 1928, s. 617). Kırmız et yerine balık tüketen Sistersiyenler bundan dolayı denizden ziyade tatlı su balıkçıllğı yapmaktaydılar. Çünkü değirmenler için su depolanan küçük göletler, sulamada kullandıkları kanallar, 
barajlar ve birçok dere yatağı onlara mükemmel bir firsat sunmaktaydı (Bouchard, 2009, s. 112). Ayrıca bazı manastıllar balık yetiştirmek için hususi havuzlara sahiplerdi. Öyle ki "balıkçlık ustası" (magister piscium) denilen kişilerin yönetiminde bu alanda ünlü olmuşlardı. Örneğin Almanya'daki Yukarı Pfalz'da 1133 'te kurulmuş olan Waldsassen manastırı XII. yüzyıldan itibaren başarllı bir balık üretim çiftliğine sahipti. Söz konusu manastır, sonrasında birçok arazisini kaybetmiş olmasına karşın 1571'de elinde hala faaliyette olan 159 gölet bulunmaktaydı. Havuzlarda alabalık, turnabalığ ve sazan balığ1 üretilmekte olup, genellikle Bohemya'ya satmaktaydılar (Lekai, 1958, s. 217). İngiltere'deki Fountains manastırının Cayton'daki küçük barajlarında balık çiftlikleri vardı. Yine Fountains manastırına bağlı Haddockstones'deki balık çiftliklerinde tütsüleme işlemi için atölyeler yer almaktaydı (Burton \& Kerr, 2011, s. 173-174). İsveç'te, iklimin tarıma uygun olmaması hasebiyle balıkçılık, manastırlar açısından çok daha büyük öneme sahipti (Lekai, 1958, s. 219).

\section{Madencilik}

Sistersiyen ekonomisi temelde tarım ve hayvancilğga dayanmakla birlikte bazı ülkelerde manastırlar madencilikte öncü olmuşlardı. Kömür, demir, değerli metaller ve özellikle tuz üretimi İskoçya, Almanya ve Avusturya'da oldukça gelişmiştir. Rein manastırı tarafindan Aussee'de (Avusturya) 1147'de işletmeye açılan yatak, ilk Sistersiyen tuz yatağı olmasının yanı sıra Steiermark bölgesinin de ilk önemli tuz üretim merkeziydi (Lekai, 1958, s. 221). Burgonya'da Macon'da XII. yüzyll ortaları gibi erken dönemden itibaren tuz üretmekteydiler (Bouchard, 2009, s. 117). İtalya'da Adriyatik kiyısinda Brondolo ve Chioggia, Sistersiyenlere ait önemli tuz üretim merkezlerdendi (Burton \& Kerr, 2011, s. 174). İskoçya'daki Newbattle ve Culross manastırları, çıkardıkları tuzu gemilerle ihraç etmekteydiler (Barrett, 1913, s. 170). Bazen bu konuda manastırlar arasında rekabet yaşandığı olurdu. Altencampen manastırı başrahibi, 1298'de Neuencampen başrahibini ziyaret ederken, onunla Lüneburg'daki tuz tavasının kullanım konusunu görüşmüştü. Öte yandan Reinfeld, Dobberan ve Scharnebeck manastırları da aynı bölgede hak talep etmekteydi. Hatta 1326-1329 arasında Amelungsborn manastırı da bu yarışa katılmıştı (Thompson, 1928, s. 617).

Tarikat metalürji alanında da faaliyetler yürütmüştür. Kendi ihtiyaçlarını karşılamak için başladıklanı demir üretiminde zamanla, diğer alanlarda olduğu gibi, üretim fazlalarını satmaya başlamışlardı (Gimpel, 2004, s. 64). 1080 'den 1130 'a kadar demir üretimi zaten Fransa'nın kuzeyinde, Rhineland'da ve Lombardiya'da gelişmişti. 1150'den sonra ise Othe ormanından Lincoln'e, Languedoc'tan Vestfalya'ya kadar Sistersiyenlerin demir üretimi büyük ilerleme kat etmişti. Önceden de zikrettiğimiz üzere ocaklardan elde edilen cürufun tarım arazilerinde kullanılmasına bağlı olarak bundan ayrıca istifade etmekteydiler (Fossier, 2008, s. 44). Kendilerine bağışlanan her demir cevheri yatağının yanında genellikle demirhane de mevcuttu. Bu tür bağışlarla birlikte genellikle demir cevherini fırınlarında işleyebilmeleri için yakınlardaki ormanlardan yararlanabilme yetkisi de almaktaydılar. Nitekim bu yetki olmadan demir yataklarının hiçbir değeri olmazdı. Fransa'daki geniş demir yataklarından birinin merkezinde yer alan Clairvaux manastırı ya bağış ya da satın alma yoluyla yakınlarındaki demir madenlerinin birçoğunu ele geçirmiş olup, XVIII. yüzyıla kadar buradaki demir yataklarını ve demirhaneleri kontrolünde tutmayı başarmıştır. 1250'den XVII. yüzylla kadar Sistersiyenler Champagne yöresinde demir üretiminde ilk sırada gelmekteydiler. Bununla da kalmayan tarikat, aynı yüzylın sonuna doğru Plateau de Langres'daki demir ve çelik üretim merkezlerinin yarısını ele geçirmişti. 1330'a kadar yaklaşık on tane demir fabrikasının sahibi olmuşlardı (Aşıkoğlu, 2009, s. 51; Gimpel, 2004, s. 65-66). Walkenried manastırı, Harz dağlarında muhtelif maden işletmeciliğine sahipti (Lekai, 1958, s. 221).

Ticari açılan çok fazla olmamakla birlikte demirin yanı sıra başka madenlerden de istifade etmişlerdir. Bohemya'daki Sedlac rahipleri 1282'de bir kısmı kendi topraklarında yer alan Kutna Hora'da gümüş madeni çıkarmaktaydılar. Almanya'daki Waldsassen manastırına bağlı Sedlitz manastırı, Kuttenberg'de gümüş madeni çıkarmıştı. Waldsassen manastırı, 1230 yllında kendi bölgesinde madencilik için kapsamlı ayrıcalıklar elde etmiş ancak etkili bir biçimde üretime geçmesi XV. yüzyılı bulmuştur. Sistersiyenler açısından ticari emtia olmasının ötesinde kurşun üretimi ihtiyaç arz etmekteydi. Çünkü manastırların çatısını örtmede, boru yapımında ve pencerelerdeki işlemeler başta olmak üzere birçok alanda bu madenden faydalanmaktaydılar. Strata Florida manastırı yakınlarında bulunan Cwmystwyth'deki 
madenlerden kurşunun yanı sıra gümüş ve çinko da çıkarılmaktaydı. İngiltere'deki Fountains manastırı kuruluşundan kısa bir süre sonra, bölgedeki eski kurşun madenlerini çalıştırmaya başlamış, eritme tesisleri kurmuş ve çevredeki tüm maden haklarına sahip olmuştur. Aşağı Saksonya'daki bakır madeni yataklarına sahip olan Walkenreid manastırn bunların işletmeciliğini de kendisi yapmaktaydı (Lekai, 1958, s. 221; Burton \& Kerr, 2011, s. 181). 1140'da kurulmuş olan ve İskoçya'daki en eski Sistersiyen yerleşimlerinden Newbattle manastırı, bölgenin ilk kömür madenlerinden birini açmıs olup, bu ocakların kalıntıları günümüze ulaşmıştır (Barrett, 1913, s. 150). 1217'de kurulmuş olan Culross manastırı büyük bir kömür üreticisiydi. Çıkardıkları kömürü yakındaki limanlara ulaştırıp, buradan da yaklaşık 170 gemiyle ihraç etmekteydiler (Barrett, 1913, s. 170).

\section{Endüstri}

Sistersiyenler elde ettikleri ürünleri, Aziz Benedikt kurallarının belirttiği doğrultuda manastır içinde kurdukları atölyelerde işlemekteydiler. Buralarda tekstil, dericilik, ayakkabıcılık, tarım aletleri ve muhtelif ev gereçleri üretimi yapılmaktaydı. Örneğin Foigny manastırında (Fransa) bir bira atölyesi, bir cam atölyesi, 2 yün eğirme atölyesi ve 3 demirhane bulunmaktaydı (Lekai, 1958, s. 220). Bu üretim işlemi için ihtiyaç duydukları en büyük enerji kaynağ1 su gücü olmuştur. Hatta Sistersiyen tarikatının kuralları, manastırların nehir kenarlarında kurulmasını ve su gücünden yararlanılmasını önermekteydi. Onların sahip oldukları mekanik donanım, manastırlar için olağan bir durum olmakla birlikte, kentler bu konuda daha geriden gelmekteydi (Mumford, 2007, s. 323). XII. yüzyllda kaleme alınmış Clairvaux manastırı raporunda, tahıl öğütme, un eleme, kumaş çırpma ve dericilik olmak üzere dört alanda su gücünden istifade edildiği nakledilmektedir. Aynı zamanda, keşişlerin içeceği biranın mayalandırıldığı kazanların kurulu olduğu ocaklardaki körüklerin çalıstırılmasında da su gücü kullanılmaktaydı (Gimpel, 2004, s. 5). Fontenay'daki demirhanede, XII. yüzyılda su gücüne dayalı mekanik bir çekiç kullanıldığı söylenmektedir (Gimpel, 2004, s. 5). O zamanlar Avrupa'da bulunan 742 tane manastır için de yukarıdakine benzer içerikte raporlar vardır. $\mathrm{Bu}$ da Sistersiyenlerin manastırlardaki makineleşme konusunda ne kadar iyi olduklarını göstermektedir (Jamroziak, 2003, s. 200). Aziz Bernard döneminde Migne'deki Sistersiyen manastıryla ilgili bir tasviri Mumford șu șekilde nakletmektedir: "Nebir manastırn içine, akısım durduran kuyunun iæìn verdiğince girer. Önce un değirmenine akar, orada tanelerin tekerleklerin ağırliğ altında ögütülmesinde ve unla kepeği birbirinden ayıran ince eleğin sallanmasinda is görïr. Oradan diğer binaya geģer ve bağlarn veriminin, şarap yapımcısm memnun etmediği

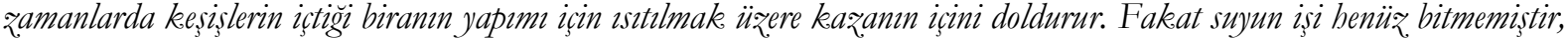
zira oradan da un değirmenini takip eden çupuc dibeğine gider... Şimdiki göreviyse kardeşlerin giveceğini hažrlamakttr...

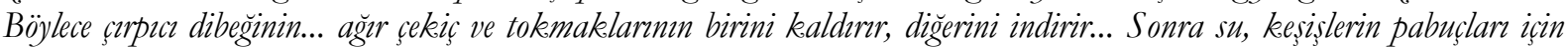
gerekli olan en önemli malz̧emenin yapımı için tabakhaneye girer. Sonra birçok. kola ayrlhp çeşitli bölümlerden geçer. Geçtiği her yerde hangi is için elinden ne geliyorsa yapar... Bir șeyleri döndürür, ezer, sular, yıkar, ögütür... Sonunda, binlerce teşekekür kaz̧anmıs ve ardinda yapılmadık hiçbir iş burakmamıs balde çöpleri de alip, her seyi tertemiz brrakarak çeker gider." (Mumford, 2007, s. 323).

Su gücünün en çok faydalanıldığ yer su değirmenleri olmuştur. Manastırların büyük bir kısmında değirmen bulunmaktaydı. 1480'de 14 su değirmeni işleten Zinna'da (Almanya) olduğu gibi, değirmencilik manastırların ana üretim aracına dönüşmüştü (Lekai, 1958, s. 220). Birçok yerde su değirmeni inşası için su yataklarının kullanım imtiyazı alınmıstır. Yine düzenli su tedariki için küçük barajlar yapılmısstır (Berman, 1986, s. 89). Batı Avrupa'da X. ve XI. yüzyıllarda denizin gel-git akıntısından faydalanılarak değirmenler inşa edilmeye başlanmıştı. Scheldt nehrinin halici, Anvers, Zeeland, Zierikzee ve Tholen yakınlarında bunlardan vardı. Sistersiyenler özellikle Zeeland'da (Hollanda) bu teknikle çok sayıda değirmen inşa etmişti (Bavel, 2010, s. 159). Birbirinden binlerce mil uzaklıkta yer alan Portekiz, İsveç, İskoçya, Macaristan gibi ülkelerde neredeyse aynı plan üzerine kurulmuş manastırların hepsindeki su gücüne dayalı sistemler birbirine çok benzemekteydi. Söylentiye göre, kör bir Sistersiyen keşişi bu manastırlardan herhangi birine girecek olsa hiç yabancillk çekmeyeceği ifade edilmektedir (Gimpel, 2004, s. 3). Benzer şekilde Sistersiyenler metalürji alanında gerek kendi buldukları gerekse başkasının bulduğu yenilikleri geniş manastır ağ1 sayesinde hızla farklı bölgelere taşımaktaydılar (Gimpel, 2004, s. 64).

İlk Sistersiyenler değirmen, fırın vb. üretim yerlerinin kullanımından kira alınmasını yasaklamışlardı. Onlara göre en uygun gelir, kendi topraklarında çalısarak alın teriyle kazandıklarıydı (Burton \& Kerr, 2011, 
s. 160). Ancak sonrasında bunu bir gelir kapısı olarak görmüşler hatta kendilerine rakip olunmasından hoşlanmamışlardı. Değirmen işletmede o kadar ilerideydiler ki bazen bulundukları bölgede tekel kurup tahıl ekimini kontrol etmekteydiler. Çünkü çiftçi, ürünlerini değirmenler vasıtasıyla elden çıarmak zorundaydı. Değirmenler üzerine tam olarak tekel kuramadıkları bölgelerde rekabet edebilecek diğer değirmenlerin kurulmasını önlemek için suların kullanım hakkını ele geçirmişlerdi. Mecklenburg ve Neuencampen'deki manastırlar bunu başarılyla gerçekleştirmişti (Thompson, 1928, s. 617). Örneğin Chantilly yakınlarında, Royaumont'daki bir Sistersiyen manastırına bağlı keşişler, Pierre de Baclai adında birinin, Gonesse'deki kendi değirmenlerine doğrudan rakip olacak bir yel değirmeni yaptırması üzerine çok hiddetlenmişlerdi. Keşişlerin tehditleri boşa çıkınca, sorunu mahkemeye götürmüşler lakin yargıç her iki tarafı da dinledikten sonra, Pierre de Baclai'ye ait değirmenin yıktırllma talebini reddetmişti (Gimpel, 2004, s. 26). Almanya'nın bazı yerlerinde de değirmencilikte tekel sahibi olmuşlardı. XIII. yüzyılda Reinfeld ve Doberan bölgesindeki hem su ile hem de rüzgâr ile çalışan tüm değirmenleri satın almışlardı (Lekai, 1958, s. 220). Bu süreçte bazı kişiler ellerindeki değirmenlerin bakımlarını karşılayamadıklarından kullanım hakkını Sistersiyenlere devretmekteydi (Berman, 1986, s. 87). Sonuç itibariyle özellikle XII. yüzyıldan sonra firınların yanı sıra değirmenlerden elde ettikleri gelirler, yüklü bir kaynak olmuştur (Bouchard, 2009, s. 115). Fakat XIII. yüzyl sonlarından itibaren laik biraderlerin sayısının azalması neticesinde değirmenler gerektiği biçimde işletilemeyince köylülere kiralanmaya başlanmıştı (Lekai, 1958, s. 220).

Sistersiyen değirmenleri, halk tarafindan yoğun şekilde kullanılmaktaydı. Öyle ki buralar, yakın zamana kadar Anadolu'da olduğu gibi buluşma yeri olmuştu. Kalabalık olması hasebiyle tahıllarını öğütmek isteyenler buralarda sıra beklemekteydiler. Bekleyenlerin sayısı öyle çok olurdu ki bazen değirmenin dışındaki açık alanlara taşarlardı. Hatta kalabalıktan yararlanmak isteyen hayat kadınları da buralara gelip müşteri bulmaya çalısırlardı (Gimpel, 2004, s. 1; Le Goff, 2015, s. 345). Bunu duyan Aziz Bernard, yazdığ1 mektup ile (81 nolu mektup) durumdan rahatsızlığını dile getirmişti. $\mathrm{O}$, ya kadınların değirmenlere girmelerinin yasaklanmasını veya değirmenlerin işletmeciliğinin laik biraderlerin ve diğer manastır dışı kişilerin kullanımından alınmasını önermişti. Şayet bu şekilde önlem alınmadıktan sonra her şeyin akışına bırakılmış olacağını ifade etmekteydi (Bernard of Clairvaux, 1998, s. 119). Gimpel ise eserinde kaynağını belirtmemekle birlikte Bernard'nn değirmenlerin kapatılmasını istediğini ileri sürmüsstür. Ancak o dönemin en büyük enerji kaynağının kapatılmasının mümkün olmaması hasebiyle bunu gerçekleştiremediğini ileri sürmektedir. Nitekim Gimpel, böyle bir kararın etkisinin 1973’te Orta Doğu'daki petrol üreticisi ülkelerin bazı Batı ülkelerine uyguladıkları petrol ambargosu ile benzer bir netice doğuracağını ifade etmektedir (Gimpel, 2004, s. 3).

\section{Ticaret}

Sistersiyen ekonomisinin doğuşunun öncelikle kendi ihtiyaçlarını karşılamak için ortaya çıktığından söz etmiştik. Ancak oluşan ihtiyaç fazlası üretim, zamanla onların ticarete girmelerini sağlamışırı. Yani tarikatın amacı başlangıçta kendi kendine yeten kapalı bir ekonomiye sahip olmaktı (Burton \& Kerr, 2011, s. 177). İhtiyaçlarının çoğunu karşılamaktaydılar ancak bu hepsi için mümkün olmamaktaydı. Buna mukabil ellerinde ihtiyaç fazlası ürünleri nakde dönüştürerek bu sorunu çözmeye başlamışlardı. Fakat ilk yıllarda Sistersiyen mevzuatı ticareti yasaklamış olduğundan, bununla ilgili defalarca düzenlemeler yapılmıştır. Önceleri kendi çiftlik ürünlerini makul bir fiyata satmak ve manastır için gerekli olan şeyleri satın almak için yalnızca iki laik birader veya keşişin en yakın pazar yerini belirli bir süre ziyaret etmesine izin verilmekteydi. Ayrıca bu işlem sırasında, daha yüksek fiyata satmak amacıyla nakit yerine başka bir ticari mal alınması yasaklanmıştı. Hatta "denizaşırı" ticaret de hoş karşılanmamaktaydı (Lekai, 1958, s. 213-214). 1157 'den önce hiçbir manastır mensubunun mal satın almak veya satmak için, manastırdan bir günlük uzaklıktan fazla bir yolculuğa çıkmasına müsaade edilmemekteydi. $\mathrm{O}$ yll yine kural değişikliğine gidilmiş ve dört günlük bir mesafeye gidilebilmesine müsaade edilmişti (Thompson, 1928, s. 620). Manastırın değerlendiremediği fazla ürünler ise fakirlere, misafirlere veya ücretli işçilere dağıtılmaktaydı (Lekai, 1958, s. 214).

Zamanla üretilen ürünlerin çiftliklerden uzak manastırlara taşınmasındansa yakınlardaki pazarlarda nakde dönüştürülmesi daha pratik bulunmuş ve bu da Sistersiyen ticaretini artıran unsurlardan olmuştur. Devamında malların değişimini veya satışını kolay bir şekilde yapabilmek için pazarın bulunduğu 
kasabalardan mülk satın almışlardı. Böylece XII. yüzyıl ortaları gibi erken bir tarihten itibaren yerel pazarlarda kendilerini göstermeye başlamışlardı. Örneğin bu tarihlerde Rein manastırı Graz kasabasındaki (Avusturya) dükkânlarında şarap ve tarım ürünleri satmaktaydı. XII. yüzyllın sonlarından itibaren Tarikatın ticari faaliyetlerinin yoğunluğu artmış ve diğer kentlerle de irtibat kurarak kırsal görünümden çıkmaya başlamışlardı. Şüphesiz bu, bölgeden bölgeye farklılık arz etmekteydi. Güney Fransa'daki manastırlar XII. yüzyıl sonlarında ticari bir kimliğe sahip olurlarken, Danimarka'daki manastılar XIII. yüzyıl sonlarında bunu başarmışlardı (Burton \& Kerr, 2011, s. 182-183).

Sistersiyenlerin en önemli iki ticaret kaleminden birincisi şaraptı. 1134'e kadar şarap satışı yapılmamaktaydı ancak sonrasında bu konuda esnemeye gidilmiştir. XII. yüzyılın sonlarında, manastırların üzüm bağları o kadar artmıştı ki ihtiyaç fazlası ürün için pazar arayışlarına gidilmişti. Bazı manastırlarda laik biraderler, duvarların hemen dışında kabinler kurarak satış yapmaktaydılar (Thompson, 1928, s. 621). Burgonya nehir sistemi, keşişlere şaraplarını Paris ve Lyon'un büyüyen kent pazarlannna taşımaları için kolay ulaşım imkânı sağlamaktaydı (Bouchard, 2009, s. 104). Eberbach manastırı XII. yüzyıllın ortalarından itibaren, yılda ortalama 53.000 galon şarab1 gümrük vergisi ödemeden Ren nehrini kullanarak kendi gemileriyle Köln'e ulaştırıp burada yerel tüccarlara toptan satmaktaydı (Gimpel, 2004, s. 47; Lekai, 1958, s. 216). Eberbach manastırı ününü asıl, 1500'lü yıllarda yaptıkları dünyaca ünlü "Dev Eberbach Fiçısı"na borçlu idi. Yaklaşık 9 metre uzunluğunda ve 3 metre çapındaki bu fiçı 70.000 litre kapasiteye sahip olup, 14 çemberle bir arada tutulmaktaydı. XIV yüzyll şairlerinden Vincent Obsopoeu bu fiçıyı dünyanın sekizinci harikası olarak görmekteydi (Gately, 2014, s. 106; Lekai, 1958, s. 216). Şarap ticaretinde öne çıkan bir diğer manastır olan Walkenried manastırı, şarap satışı için Würzburg kasabasında 1206'da bir mahzen ve bir mağaza inşa etmişti (Lekai, 1958, s. 217).

Sistersiyenlerin Kıta'daki ticari faaliyetlerinde şarap ön planda yer alırken, geniş meraların olduğu İngiltere'de bunun yerini yün almıştır. Yorkshire'daki büyük koyun çiftçiliği, adadaki ilk Sistersiyen girişimiydi. Tarikat kısa zamanda İngiltere'nin en önemli yün ihracatçısı olmuştu. Kendisine ait manastırların olduğu Boston ve Hull önemli limanlar olmuşlard. Ayrıca bu şehirlerde yoğun bir şekilde yabancı tüccarlar bulunmaktaydı(Lekai, 1958, s. 214). Tarikat yün üretiminde öyle zenginleşmişti ki 1198'de Kral I. Richard'in fidyesinin 4 üçte birinden fazlasını onlar ödemișlerdi (Lekai, 1958, s. 215). İngiliz yününün kalitesi Kıta'da iyi bilinmekteydi ancak Sistersiyenlerle birlikte özellikle XII. ve XIII. yüzyıllarda bu alanda daha da ilerlemişlerdi. Muhtemelen, keşişlerin daha iyi yetiştirme teknikleri uygulamaları ve yünleri titizlikle hazırlayıp kalitesine göre sınıflandırmaları neticesinde bu farklılık ortaya çıkmıştır. Örneğin Fountains manastır1 yünlerini altı kategoriye ayırmaktaydı (Bell vd., 2007, s. 117; Burton \& Kerr, 2011, s. 185). Büyük miktarda yün üretmelerine rağmen başkaları tarafindan üretilen yünün satışını da yapmaktaydılar. Yünlerini satmak için aracıya ihtiyaç duyan küçük üreticiler ya manastırlara müracaat etmekte veya büyük tüccarların kapısını çalmaktaydılar. Ancak Sistersiyenler, dışarıdan aldıkları bu yünleri satarken kendi yünlerinden ayrı tutmaktaydılar. Kanaatimizce, kendi marka değerlerini korumak amacıyla böyle yapıyorlardı. Ağır bir iş olmamasına rağmen, koro rahiplerinin manevi izolasyonunu korumak için üretim faaliyetlerinde olduğu gibi yün ticaretinde de laik biraderlerden faydalanmaktaydılar (Madden, 1963, s.343- 344).

Sistersiyen yünleri hem Lincoln ve Stamford gibi tekstil üretiminde öne çıkmış iç pazarlarda kullanılmakta hem de dış piyasaya ihraç edilmekteydi. O dönem Rievaulx'un da içinde yer aldığı birçok Sistersiyen manastırı her iki pazara ürün arz ederek önemli gelir elde etmekteydiler. Özellikle Flandre'deki tekstil endüstrisi güçlendikçe yün, İngiltere'deki en önemli ihracat kalemi olmuştur. Nitekim XIII. yüzyıl ortalarına kadar İngiltere'den yapılan yün ihracatının çoğunu Flandreli tüccarlar almaktaydı. Ancak İngiltere'deki II. Baronlar savaş1 ve 1264'te İngiltere ile Flandre arasındaki savaş neticesinde iki ülke ticaretinde sorunlar yaşanmıştır. 1264 yazında İngiltere limanları kapatılmış ve baronlar, tüccarlara yönelik muhtelif yaptırımlara girişmişlerdi. Yaklaşık on yıl süren uzun karışıklıklar ve engellemeler, İngiliz yün ihracatını zayıflatmıştı (Jamroziak, 2003, s. 200-201). Siyasi kriz son bulduktan sonra bazı Flandreli

\footnotetext{
${ }^{4}$ Kraliyet memurları, hiç kimseyi istisna tutmadan İngiltere genelinde fidye için hazırlıklara girişmişti. Profan, din adamı, çiftçi, soylu hepsi bu talebin muhatabıydı. Kilise ve manastırların imtiyazları, ayrıcalıkları, dokunulmazlıkları da mazeret kabul edilmemişti. O zamana kadar birçok vergiden muaf tutulmuş olan Sistersiyenler bile kamu baskısının ağırlı̆ı̆ndan dolayı bu fidyenin ödenmesine katkıda bulunmak zorunda kalmışlardı. Bkz. William of Newbubgh, 1856, s. 615.
} 
tüccarlar 1275 'te İngiltere'ye geri dönmüşler lakin geçen süre zarfinda özellikle Sistersiyen manastırlarının çoğu İtalyanlarla antlaşma yapmışlardı (Lloyd, 1977, s. 39). Rievaulx manastırı ile ticaret yapan İtalyan şirketler arasında Luccalı Riccardi, Floransalı Frescobaldi ve Mozzi öne çıkmaktadır. Bu tüccarlar toplam yünün yüzde 50'sinden fazlasını almaktaydılar. Dahası 1294'te İtalyan tüccarlar, en kaliteli yün üreten yetmiş dört Sistersiyen manastırından kırk dokuzundan yün satın almaktaydılar (Bell vd., 2007, s. 116). Bunlardan Riccardi 1275-1294 arasındaki yün ticaretinde elde ettiği ayrıcalıkların bedeli olarak Kral Edward'a borç veren önemli bir banker olmuştur. Riccardi 1299'da bölgeden çekilince bu kez yine Rievaulx manastırının bir diğer İtalyan ortağı Frescobaldi, 1302'de onun pazarına sahip olmuştur (Jamroziak, 2003, s. 201). Bu süreçte Yorkshire manastırları Flandre ve İtalya ile yün ticaretini kolaylaştırmak için Boston ve York'ta mülkler edinmişlerdi (Burton \& Kerr, 2011, s. 185).

Ticari faaliyetlerin seyrine göre tarikat mevzuatında sürekli değişiklikler yaşandığını belirtmiştik. 1157'deki genel kurulda avansla satışlar yani ürün bedelini birkaç yil öncesinden alıp ürünün sonra teslim edilmesi yasaklanmıştı. Muhtemelen rekabet koşullarına ayak uydurulabilmesi için 1181'de bu konuda esneme yapılmış ve avans sonrası ürün tesliminin bir ylla kadar uzatılabilmesine ruhsat verilmişti. 1189'daki genel kurulda Yahudilerle alışveriş yasaklanmış olmasına karşın bu kural pratikte de delinmekteydi. Sik sık nakde ihtiyaç duyan manastırlar, bundan dolayı Yahudilerle finansal ilişkilerini sürdürmekteydiler. Öyle ki vergiden muaf olan manastırlar, Yahudilerle yapılan alısverişte, dolaylı vergi ödemelerine rağmen bunu sürdürmekteydiler. İlginçtir ki İngiliz manastırlarının kendileri genellikle borçlu olmalarına karşın bazen nakde ihtiyaç duyan lortlara finansal destek sağlamaktaydılar. Anladığımız kadarıyla bu ilişki, başta tarım faaliyetleri ve arazi mülkiyetlerine dayanan teminat koşullarında devam etmekteydi. Hatta Yahudilere borcu olan kişilerin borcunu ödeyip, onların arazilerini kullanmakta, bazen de tamamen el koymaktaydılar (Madden, 1963, s. 346-347).

Manastırlar birer ticari kurum haline gelmiş olmalarına karşın vergi, pazar giriş ücreti, köprü geçiş ücreti gibi ödemelerden muaftılar (Bouchard, 2009, s. 111). Büyüyen manastır endüstrisi ve ticareti dolaylı olarak, şehirlerin refahını artırmıştı. Ancak vergiden muaf olan manastırlar, yerel tüccarlardan çok daha uygun fiyata ürün satmalarından dolayı diğer satıcıların tepkisini çekmekteydiler. Bunun içindir ki bazen manastırlar, mallarını başka yerlerde hatta kendi sınırları içinde satmaya zorlanmıştır. Waldsassen manastırı, Macaristan'daki Eger şehri ile böyle bir rekabet neticesinde anlaşmazlığa düşünce, XIV. yüzyılda kendi topraklarında iki yeni ticaret merkezi kurmuştur. Eberbach manastırı ile Köln şehri ve Bebenhausen manastırı ile Ulm şehri arasında da benzer anlaşmazlıklar yaşanmış ancak sonunda şehirlerin istediği olmuştu (Lekai, 1958, s. 222). Fountains manastırı kurşun ticaretinde hırsı ve başarısı ile lider bir pozisyon elde etmişti ki bu durum diğer tüccarlar açısından bir tehdit oluşturmaktaydı. York'taki tüccar birliği, Sistersiyenlerin tekel oluşturmasından korkmuş ve Fountains manastırı başrahibi Huby'ye (1495-1526) mektup yazarak manastırın bu girişimini durdurmasını istemişti. Ancak başrahip onların bu talebini dikkate almamış ve Sistersiyenler de ticaretlerine devam etmişlerdi (Burton \& Kerr, 2011, s. 182).

Görüldüğü üzere Sistersiyenlerin ticari hırsları bir tarikata göre oldukça fazlaydı. Onların hem tekelleşmeleri hem de arazi kazanma hırsları hususunda, kendisi de bir Sistersiyen olan John of Forde'un 1184'te kaleme aldığı Wulfric of Haselbury'nin Hayat isimli eserde değinilmişstir. Eserde Wulfric, Sistersiyenlerin sahip oldukları topraklarda kendilerine verilmiş hakları çok hoyratça kullanmalarından ve bölgenin lortlarına karşı görevlerini yerine getirmemelerinden yakınmaktaydı. Onlanı toprak için gerektiğinde zora başvurmaktan çekinmeyen hilekâr ve açgözlü şahıslar olarak tanımlamaktaydı. Örneğin Louth Park manastırının (Lincolnshire) rahipleri, Cockerington malikânesinin sahibi Henry le Vavasour'un varlığını devretmesi için 1342'de çalışmalar yapmışlardı. Louth Park başrahibi, Henry'yi üstü kapalı bir arabayla evinden aldırtmış ve şahitler huzurunda gerekli evrakları imzalaması için ısrar etmişti. Henry'nin dul eşi Constance, kocası öldükten sonra bu sözleşmenin geçersiz olduğunu iddia etmiş ve kocasının vasiyetini verirken sağlıklı olmadığını, orada tedavi edileceğine inandırılarak götürüldüğünü söylemişti. Gerald of Wales, çalışkanlıklarıyla Sistersiyenleri överken açgözlülüklerini de sert bir şekilde eleştirmektedir. O, Herefordshire'daki Ewyas Harold'da ölüm döşeğindeki zengin bir kadını birkaç keşişin ziyaret ettiğini ve bu keşişlerin söz konusu kadından, mülkünü kendilerine devretme sözü almadan oradan ayrılmadıklarını iddia etmektedir (Burton \& Kerr, 2011, s. 186-187). Bu örneklere rağmen o dönem 
Sistersiyenlere mesafeli olan isimlerden gelen nakillerin abartll olma ihtimalini hesaba katmamı gerekmektedir.

\section{Sistersiyen Ekonomisinin Zayıflamas1}

Genel olarak 1150-1250 y1lları arasında ekonomik alanda büyük başarnlar elde eden Sistersiyenler XIII. yüzyıl ortalarından itibaren finansal bir krizin içine doğru girmişlerdi. İlk olarak İngiltere'deki Sistersiyen manastırlarının yün ticareti XIII. yüzyllın ikinci yarısından itibaren zayıflamaya başlamışı. Yorkshire başta olmak üzere ülke genelinde ortaya çıan koyun kabuğu hastalı̆̆ından (murrain) dolayı yün üretimi düşmüştü. 1258-1317 yılları arasında dört kez görülen bu hastalık neticesinde manastırlar önemli sayıda hayvan kaybetmişler ve iflasın eşiğine gelmişlerdi. Bunun neticesinde yün arzı azalmış ve manastırların borcu artmışt1 (Bell vd., 2007, s. 69). Akabinde icra yoluyla tahsilatlar başlayınca, 1270-1290 yılları arasında Kirkstall, Flaxley, Missenden ve Rievaulx manastırları tasfiye süreçleri ile karşılaşmışlardı. 1285'te koyun sürülerini kaybeden Kirkstall manastırı, dışarıdan daha fazla yün satın alıp yüklü miktarda avans aldığı Flanderli tüccarlara vererek sorunu aşmaya çalışışstı (Lloyd, 1977, s. 290). XIII. yüzyılda derin borç batağına saplanmış olan manastır sayısı oldukça fazlaydı. 1318'de genel toplantıda karamsar bir şekilde “Tarikat, yoksulluğun derinliklerine doğru yöneliyor” denmişti. Yalnızca küçük manastırlar değil çok büyük sermayeye sahip manastırlar da bu krizden etkilenmişlerdi. Lortlar gibi piskoposlar ve başrahipler de toprakları üzerindeki kontrollerini kaybetmişler ve geleneksel toprak düzenini bırakıp arazilerin kiralanmasını kabul etmek zorunda kalmışlardı (Lekai, 1958, s. 222-226). XIV. yüzyıla gelindiğinde ise Avrupa'nın çoğunda olduğu gibi Sistersiyenler için de zor bir sürece girilmişti. Manastırlar büyük miktarda borç yükü altında ezilirken, veba salgını sonrasında laik biraderlerin sayısında azalma yaşanmış ve çiftliklerin idaresi zor bir hal almıştı. Avrupa çapında etkisini gösteren Yüz Yıl Savaşları, bunalımı artıran bir diğer etken olmuştur (Burton \& Kerr, 2011, s. 175). Özellikle 1350 ile 1450 yılları arasında fiyatlarda büyük düşüşler yaşanmıştır. Heaton bunu arzın artısı olarak izah etmekle birlikte kanaatimizce talebin azalması da bunda etkili olmuştur (Heaton, 1985, s. 125).

\section{Orta Çă̆ Avrupa'sında Yerleşime Etkileri}

Sistersiyenler XII-XIII. yüzyıl Avrupa'sında ekonomik alanda iz bırakırken bunun yerleşim ve şehirleşme hususunda tesirleri olmuştur. Birçok manastırın, yakınlarındaki şehirlere erzak temini noktasında önemli katkıları olmuştur (Bavel, 2010, s. 223). Ayrıca tarımsal faaliyetlerin artması yeni kasabaların doğuşuna ve kent nüfusunun artışına zemin hazırlamıştır. Bunun en güzel örneği Almanya’nın doğusunda görülmektedir. Bu bölgede ormanları temizleyip, bataklıkları kuruttuktan sonra, "Eski Batı" diye tanımlanan Elbe nehrinin batısındaki bölgelerden, yeni iskâna açılan alanlara yerleşimci getirmişlerdi. Bu iskân politikasına yerel yöneticiler öncülük etmekteydi ancak hem yeni arazilerin tarıma açılmasındaki yoğun gayretleri hem de göçmenlerin doğuya ulaştırılması aşamasında yol güzergâhlarında pansiyon işlevi görmeleri hasebiyle Sistersiyen manastırları oldukça önemli bir yere sahiplerdi. Tarikat mensupları "uygarlaştırdıkları"nı ifade ettikleri Silezya'nın önceki halini korkunç biçimde resmetmekteydiler. Onlara göre bu ülke, "Bir çift cılız inek veya öküz tarafindan sürülen, fakir ve tembel Polonyalıların yaşadığı bir orman diyarı" idi. Yine bu insanların tuz, metal, ayakkabı gibi basit malzemeleri bile kullanamadan "acınacak" bir şekilde yaşadıklarını ileri sürmekteydiler. Son olarak bu bölgede kasabaların bulunmadığını söylüyorlardı (Thompson, 1928, s. 613).

Güneybatı Fransa'da kralın isteği doğrultusunda bazı manastırlar, özellikle İngiliz kontrolündeki Gaskonya'nın sınır bölgesinde, XIII. yüzyıl ortalarından itibaren "bastide" denilen askeri yerleşim yerleri kurmuşlardı. Bunlar aynı zamanda yerel otoritelerin işlerini kolaylaştırmaktaydı. Sistersiyenlerin grange denilen büyük çiftlikleri yerel halk için bir çekim merkezi olunca bu yerleşimlerin kuruluşu kolaylaşmıstır (Berman, 1986, s. 120). Böylece Fransa kralı ile birlikte hareket eden Sistersiyenler, önceden bölgeden uzaklaşmış olan köylülerin dönmesini sağlamışlardı (Burton \& Kerr, 2011, s. 177). Ayrıca manastırların ücra ve $1 s s ı z$ yerlerde kurulması, beraberinde buralara ulaşımın sağlanması amacıyla yol yapım çalışmalarını da başlatmıştır. Bundan dolayı Sistersiyenler, dönemin önemli yol inşaatçılarından olmuşlardı (Thompson, 1928, s. 565). 
Sistersiyenlerin Avrupa'daki sosyo-ekonomik çalısmaları ile Anadolu ve Balkanlar'da faaliyet gösteren dervişlerin benzer icraatları arasında kısa bir kiyaslama yapmakta fayda görmekteyiz. Türklerin batı yönündeki ilerlemeleri sürecinde dervişler halka liderlik etmiş ve daha sonra yeni yerleşimler oluşturarak buraları ekime hazır hale getirmeye katkıda bulunmuşlardı (Lapidus, 2005, s. 419). Menakıpnamelerde dervişlerin uğradıkları ve bir süre ikamet ettikleri yerlerde, hayvan gütme, tarla işleri, köprü yapımı, bina inşaatlan, değirmenlerde zahire ögütülmesi, su sorununun çözülmesi gibi muhtelif işlerde köylülere yardım ettikleri nakledilmektedir (Ay, 2008, s. 137). Buradaki bazı dervişler elde ettikleri mahsulleri iki gözlü ambarlarına taksim edip bir gözdekileri kendilerine, diğer gözdekileri ise fakir yolculara tahsis etmekteydiler (Barkan, 1942, s. 304). Ancak onların en dikkat çeken çalışmaları Anadolu ve Balkanlar'da yeni fethedilen Hristiyan memleketlerinde olmuştur. Issız bölgelere veya yol güzergâhlarına yerleşerek, oraları imara açıp emniyetini sağlamışlardı (Barkan, 1942, s. 294). Hatta özellikle seyahat ve ticaret için tehlikeli olduğu düşünülen yerlere zaviyelerin kurulması devlet tarafından teşvik edilmiştir. Bu bakımdan dağlarda ve korkunç boğazlarda kurulan bu tesisler, Barkan'a göre jandarma karakolları gibi bir işleve sahipti (Barkan, 1942, s. 297). Dahası tekke ve zaviyelerin olduğu yerler zamanla, ticaret ve yerel yönetimlerin de merkezi haline gelmişlerdi (Lapidus, 2005, s. 450). Örneğin Niğbolu’ya bağlı Dervişler köyü bu şekilde kurulmuştur (Barkan, 1942, s. 298). Dervişlerin bu çalışmaları ile Baltık bölgesindeki Sistersiyen manastırlarının faaliyetleri arasında benzerlik olmakla birlikte önemli farkll1kklar da görülmektedir. Sistersiyenler, Almanların öncü kuvveti gibi hareket edip bölgeye yerleşirken, Hristiyanlaşmayan yerel halkın bölgeden gitmesi için idarecilerle birlikte hareket etmişlerdi (Jotischky, 2017, s. 218). Buna mukabil dervişler Balkanlar'da yerel halka dokunmamış hatta bazen "kul" denilen işçileri yerel halktan seçmişlerdi (Barkan, 1942, s. 303).

Dervişler, Sistersiyenlerin aksine kayda değer bir imtiyaza sahip değillerdi. Kendi ihtiyaçlarını kendileri karşılayıp ziraatla meşgul olmaktaydılar. Yeri geldiğinde bir asker gibi savaşmanın yanı sıra diğer zamanlarda köylü gibi bağda bahçede çalışmaktaydılar. En önemlisi de dervişlerin çoğu ilk dönemlerde öşürden bile muaf değillerdi (Barkan, 1942, s. 294). Zaviyelerin oldukları yerlerde, Sistersiyenlerin grangelerine benzemekle birlikte o denli büyük olmayan çiftlikler bulunmaktaydı (Barkan, 1942, s. 303). Devlet desteğinden yoksun olmalarına karşın bazen çeşitli bağışlar almışlardı. Aldıkları bu bağışları hamamlara, pazarlara, dükkânlara, kiralık dairelere, atölyelere, değirmenlere, mezbahanelere, tabakhanelere ve seramik fabrikalarına yatırarak uzun süreli gelir kapısı elde etmekteydiler (Lapidus, 2005, s. 450). Buna rağmen Sistersiyenler gibi uluslararası ticari bir şirket gibi çalışmamışlardı.

Bu işlerde Sistersiyenlerin faydalandığı laik biraderlere benzer şekilde "ortakçı kullar" denilen işçilerden istifade etmişlerdi. Ancak anladığımız kadarıyla Sistersiyen manastırlanında olduğu gibi bu kullar ile dervişler arasında katı bir ayrım bulunmamaktaydı. Hatta kullar, zaviyede nüfuz ve mevki kazanıp, derviş ve şeyh bile olabiliyorlardı. Birçok dervişin "Abdullah oğlu" ismiyle kayıtlı olması onlanın kul kökenli olduklarının işareti kabul edilmektedir. İlginçtir ki Rumeli'deki zaviyeler, yerel Hristiyan halktan bile kul temin etmişlerdi (Barkan, 1942, s. 303). Kullardan istifade etmelerine karşin Sistersiyenlerin aksine, kendileri de hem kamu hizmetleri hem de zaviyenin ihtiyaçlarını karşılamak için çok çalıştıklarından dolayı tasavvufi uygulamalara ayıracak pek vakitleri kalmiyordu (Ay, 2008, s. 112). Bu arada tekke ve zaviyeler, Sistersiyen manastırlarının aksine devlet denetimine tabi idi. Nitekim "âyende ve revendeye hizmette kusuru” olan zaviyeler ya fesh edilir ya da ellerinden alınıp başkasına verilirdi (Barkan, 1942, s. 299).

\section{Sonuç}

Sistersiyenler, mütevazı ve sade bir yaşam sürmek iddiasıyla yola çıkmış bir tarikattı. Kurulduktan itibaren yaklaşık üç nesil boyunca amaçladıkları gibi yaşamışlar ve tarımsal faaliyetlerin dışında farklı bir kanaldan gelir temin etmemeye gayret etmişlerdi. Lakin XII. yüzyllın ortalarından sonra durum değişmeye başlamıştır. Ekonomik kalkınma yolunda ilerleyen Sistersiyenler, Benedikten ve Kluni tarikatından farklı olarak endüstriyel faaliyetlerde değişime ayak uydurmuşlar hatta bazen değişimin öncüsü olmuşlardı. Nitekim diğer tarikatlar bunu başaramayıp soylulara ya da yöneticilere bağımlı kalırken, onlar güçlü bir ekonomiye sahip olmuşlardı. Tarikatın bu gücü bazen yaptırım aracı olarak kullanılmaktaydı. Papa IX. Gregory, yeni yeni Hristiyan olan Finlandiyalılara karşı Rusların tacizlerini durdurmak amacıyla 1229'da, 
Riga'daki Sistersiyen manastırına talimat göndermişti. Bunun için, bölgede hatırı sayllır bir ticari güç kazanmış olan tarikatın Ruslarla ticarete ara vermesini istemişti (Thompson, 1928, s. 621).

Önceleri ihtiyaç fazlasının nakde dönüştürülmesiyle başlayan tarikat-sermaye ilişkisi zamanla başta tarikat mensupları olmak üzere birçok kişi tarafindan amaçtan sapma olduğuyla ilgili eleştirilere sebep olmuştur. Pek çok manastırın sahip olduğu muazzam servet ile keşişlerin yapmış oldukları yoksulluk yemini arasındaki uyuşmazlık ortadaydi. Keşişlerin şahsi mülkleri yoktu ancak kurum olarak gelirleri çok yüksekti ve lüks içinde yaşamaktaydılar. Kendisi de bir Sistersiyen olan Heisterbach'lı Csesar, bazı Sistersiyen manastrrları öyle zenginlerdi ki isteselerdi her gün 5000 kișiyi besleyebilirlerdi diyordu (Thompson, 1928, s. 627). Kimilerine göre bu değişimin sebebi, Burgonya dışına çıkılması yani merkezden uzaklaşılmasıyla izah edilmekteydi. Ancak bu değerlendirmeyi yaparken 1150’lerden önce Burgonya'daki manastırlara ait çok az belge bulunduğunun hesaba katılması gerekmektedir (Bouchard, 2009, s. 187). XIII. yüzyıl, Sistersiyenlerin güçlerinin dorukta olduğu, buna karşllık savunduklanı değerlere sahip çıkma noktasında yozlaşmanin da başladığı bir dönem olmuştur (Thompson, 1928, s. 621). Jean Gimpel'e göre şarap tüketimi ile Sistersiyen tarikatının çöküşü arasında doğrudan bağlantı vardır. Nitekim keşiş adayları arasında yaşanan kavgalar sonucunda bazen kan dökülmüss, hatta ölümler yaşanmıştı (Gimpel, 2004, s. 49).

Sonuç itibariyle Sistersiyenler, bir yandan zenginliği, ticareti ve şehir yaşamını reddedip insanlardan uzak ıssız yerlere sığınmaya çalışıllarken, öte yandan aksi yönde hareket edip, kentlerin, panayırların ve de en önemlisi geniş bir ticaret ağının sahibi olmuşlardı (Gimpel, 2004, s. 46). O dönemde çok büyük bir bütçeye hükmetmekle birlikte, kamu yararına yönelik başlardaki faaliyetlerini azaltmış hatta yürütmekte olduğu çalışmaları durdurmuştu. Halkın ortak kullanımına yönelik yatırım yapmaktan kaçınmışlar, dahası zamanla değirmen kullananlardan bile ücret almışlardı (Thompson, 1928, s. 620). Onların ticari hırsları, sert rekabetçi yaklaşımları, halkın ve diğer ticaret erbabının tepkisine neden olmuştu. Bu olumsuzluklara rağmen tarikat XII. ve XIII. yüzyıl Avrupası'nın ekonomik yaşamında önemli izler bırakmıştır. En önemlisi de tarım ve endüstride geliştirdikleri teknikler bu alanda çok kıymet arz etmekteydi. Ayrıca bu tekniklerin manastırlar arasında yayılması sayesinde teknoloji transferi alanında önemli katkıları olmuştur.

\section{Extended Abstract}

In our study, we will consider the economic activities of the Cistercian order, which left important traces on many issues in medieval Europe. This order emerged as a reaction to the luxury lives of other orders of that period. Therefore, they attached great importance to humble lifestyle. In fact, their beginning of agricultural activities is a result of this idea. Namely, they wanted to cultivate the land and meet their own needs without being dependent on anyone.

In this process, they started working primarily in the field of agriculture and animal husbandry. Especially, they settled in unpopular places such as marshes, beaches and bushes and brought these places to the economy. They developed new techniques for this process, and they carried water to barren lands while draining water in marshes. Because more productive land was owned by someone, it was actually a necessity, not an option, for them to settle on these lands. Valleys and marshes in Northern England or Scotland, sandy areas along the coast of Bay of Biscay, Southern Baltic regions captured from Slavs, coastline where tidal streams are effective in Flanders are at the top of these areas. They established their large farms called grange on these lands and increased the settlement in their regions. As their success in agriculture increased, new land donations started to come.

The monks started production in the farms primarily to meet their own needs. However, when they started to sell surplus products in time, they entered the trade. During their commercial activities, the wide network of monasteries made their work very easy. Especially the wool produced in England has been in great demand from Flanders and Italian traders. On the continent, the main production item has been wine. The economic activities of the order were not limited to these, and they worked in every income-generating sector. As a matter of fact, they operated mines in some regions, obtained and sold timber from the forests. At that time, they became one of the important salt producers in Europe.

They proved themselves in the industrial field too. They especially benefited from water power very well. They established various facilities such as mills, bakeries, tanneries. Cistercians were producing textiles, leather, shoemaking, agricultural tools and various household appliances in the workshops they 
established. The innovation applied in one monastery at that time reached other monasteries in a short time. As a matter of fact, they became a part of technology transfer in Europe thanks to its wide network of monasteries.

While the Cistercians were carrying out these economic activities, they received various support from the rulers in the region where they were located. First of all, they didn't pay any taxes. Likewise, they entered the markets very easily and did their trade. Because they didn't pay taxes, they sold their products cheaper than other merchants. This caused the reaction of the aforementioned traders. Another issue that caused the reactions is that they went to monopolization. So much so that in most of the sectors in which they operate, they tried to dominate the market with the support of the rulers.

Another element that draws our attention to the Cistercian order is its similarities with some Muslim dervishes. We will touch upon this issue by referring to Ömer Lütfi Barkan's famous article. We especially wanted to make a comparison about the activities of dervishes in Anatolia and the Balkans during the founding period of the Ottoman Empire. As a matter of fact, these dervishes also established their lodges in deserted places and made important contributions to the security of the region as well as opening to settlement. But while the Cistercians received support from the rulers, the dervishes did not receive support, and at first they even paid eşur taxes.

As a result, the Cistercian order, which emerged as a reaction to the luxury life, then started production to meet its own needs. After that, they became enriched in such a way that they could not be identified with an order. But, they have been the pioneers of many innovations in agriculture and industry and marked a period.

Keywords: Cistercians, Monastery, Middle Ages, Mill, Wine

\section{Kaynakça}

Akın, Haydar. (2005). Ortaçağ'dan Bilge Bir Kadın Bingenli Azize Hildegard. İstanbul: Dharma Yayınları.

Ancic, Mladen. (1997). "Cistercians in Thirteenth Century Croatia”. Mediaevistik, Vol. 10, s. 205-218.

Aşıkoğlu, Yücel. (2009). Ažiz Bernard Ve Hiristiyanlık Taribindeki Yeri. (Yayımlanmamış Yüksek Lisans Tezi), İstanbul Üniversitesi Sosyal bilimler Enstitüsü Felsefe ve Din Bilimleri Anabilim Dalı, İstanbul.

Ay, Resul. (2008). Anadolu'da Dervis ve Toplum. İstanbul: Kitap Yayınevi.

Baigent, Michael \& Leigh, Richard. (2005). Tapınak Şövalyeleri Kutsal Kan Kutsal Kase. 20. Bask1, çev. Batur Özdinç - Yasemin Güneş Dulkadir. İstanbul: Nokta Yayıncılık.

Barkan, Ömer Lütfi. (1942). "İstila Devirlerinin Kolonizatör Türk Dervişleri ve Zaviyerler”. Vakıflar Umum Müdürlüğ̈̈ Neşriyatı. Say1 2, Ankara, s. 279-386.

Barrett, Michael. (1913). The Scottish Monasteries of Old. Edinburgh: Otto Schulze \& Company.

Bavel, Bas Van. (2010). Manors and Markets Economy and Society in the Low Countries 500-1600. Oxford: Oxford University Press.

Bell, Adrian R.., Brooks, Chris \& Dryburgh, Paul R.. (2007). The English Wool Market, c.1230-1327. Cambridge: Cambridge University Press.

Berman, Constance Hoffman. (1986). Medieval Agriculture, the Southern French Countryside, and the Early Sistersiyens. Washington: American Philosophical Society.

Bernard of Clairvaux. (1998). The Letters. çev. Bruno Scott James, Gloucestershire: Cistercian Publications.

Bishop, T. A. M.. (1936). "Monastic Granges in Yorkshire Author". The English Historical Review. Vol. 51, No. 202, April, s. 193- 214.

Bouchard, Constance Brittain. (2009). Holy Entrepreneurs Cistercians, Knights, and Economic Exchange in Twelfth Century. London: Cornell University Press.

Burton, Janet \& Kerr, Julie. (2011). The Cistercians in the Middle Ages. Woodbridge: The Boydell Press.

Bury, J. B.. (1926). The Cambridge Medieval V. New York: The Macmillan Company.

Cantarella, Glauco Maria. (2014). "Felsefe ve Monastisizm”. Ortaçağ - Barbarlar, Hristiyanlar,

Müslümanlar. 2. bask1, ed. Umberto Eco, çev. Leyla Tonguç Basmacı. İstanbul: Alfa, s. 381-390.

Charta Caritatis, http://archive.osb.org/cist/charta.html [Accessed: 13.02.2021]

Dalgairns, J. B.. (1898). St. Stephen Harding. Westminster: The Newman Bookshop. 
Delmas, Claude. (1967). Avrupa Uygarlık Taribi. çev. Ender Gürol. İstanbul: Akşam Kitap Klübü.

Fossier, Robert. (2008). "The Rural Economy and Demographic Growth". The new Cambridge Medieval History IV. ed. David Luscombe - Jonathan Riley Smith. Cambridge: Cambridge University Press, s. 11-46. Gately, Iain. (2014). Drink. Toronto Penguin Group.

Gerald of Wales. (2004). The Journey Through Wales. çev. Lewis Thorpe. London: Penguin Books. Gimpel, Jean. (2004). Ortaçağda Endïstri Devrimi. 6. Bask1, Ankara: Tübitak.

Heaton, Herbert. (1985). Avrupa İktisat Taribi I. çev. Mehmet Ali K1lıçbay ve Osman Aydoğuş. Ankara: Teori Yayınları.

Honour, Fleming. (2015). Dünya Sanat Taribi. Hakan Abacı (Çev.). İstanbul: Alfa.

Jamroziak, Emilia. (2003). "Rievaulx Abbey As A Wool Producer In The Late Thirteenth Century:

Sistersiyens, Sheep, And Debts". Northern History. XL: 2, September, s. 197-218.

Jotischky, Andrew. (2017). Crusading and the Crusader States. New York: Routledge.

Kienzle, Beverly Mayne. (2001). Cistercians, Heresy and Crusade in Occitania, 1145-1229. Oxford: York

Medieval Press.

Lapidus, Ira M.. (2005). İslâm Toplumlar Taribi I. çev. Yasin Aktay. İstanbul: İletişim Yayınları.

Lawrence, C.H.. (2017). Medieval Monasticism Forms of Religious Life in Western Europe in the Middle Ages.

New York: Routledge.

Le Goff, Jacques. (2015). Ortaşăg Batı Uygarlğğ. çev. Hanife Güven - Uğur Güven. Ankara: Doğu Batı Yayınları.

Lekai, Louis J.. (1958). The White Monks. Okauchee: Our Lady Of Spring Bank.

Lloyd, T.H.. (1977). The English Wool Trade in the Middle Ages. Cambridge: Cambridge University Press.

Madden, Sister James Eugene. (1963). "Business Monks, Banker Monks, Bankrupt Monks The English

Cistercians in the Thirteenth Century". The Catholic Historical Review. Vol. 49, No. 3 October, s. 341- 364.

Mason, W. A. Parker. (1905). "The Beginnings of the Cistercian Order". Transactions of the Royal

Historical Society. Vol. 19, s. 169-207.

Mumford, Lewis. (2007). Tarih Boyunca Kent. İstanbul: Ayrintı Yayınları.

Odabaşı, Zehra. (2019). "Rahip Bernard de Clairvaux: Hayatı (1090-1153). ve II. Haçlı Seferi'ndeki

Rolü”. V an Yüəz̈ncü Yal Üniversitesi Sosyal Bilimler Enstitüsü Dergisi. Say1 45, Sonbahar, s. 399-416.

Pirenne, Henri. (2012). Ortaçağ Avrupa'smmn Ekonomik ve Sosyal Taribi. 5. Bask1, çev. Uygur Kocabaşoğlu.

İstanbul: İletişim Yayınları.

Şahin, Duygu. (2020). "Geç Orta Çağ'da Fransisken Ve Dominiken Mimarisi” Sanat Tarihi Dergisi. 29/1, Nisan, s. 253-273.

Tannahill, Reah. (2003). Taribte Cinsellik. çev. Sinem Gül. Ankara: Dost Kitabevi.

Thompson, James Westfall. (1920). "The Cistercian Order and Colonization in Mediaeval Germany".

The American Journal of Theology. Vol. 24, No. 1, January, s. 67-93.

----------. (1928). An Economic And Social History Of The Middle Ages. London: The Century co.

Walter Map. (1983). De nugis curialium Courtiers' Trifles. çev. M. R. Jame. Oxford: Clarendon Press.

William of Malmesbury. (1847). Chronicle. çev. J. A. Giles. Henry g. London: Bohn.

William of Newbubgh. (1856). "The History of William of Newbubgh". The Church Histornans Of

England Vol. IV. Part II.. çev. Joseph Stevenson. Durham, s. 397-672.

Ziolkowski, Jan M.. (2018). The Juggler of Notre Dame and the Medievalizing of Modernity. Cambridge:

Openbook Publishers. 